\title{
Front Matter: Volume 10492
}

, "Front Matter: Volume 10492," Proc. SPIE 10492, Optical Interactions with Tissue and Cells XXIX, 1049201 (3 May 2018); doi: 10.1117/12.2322671

SPIE. Event: SPIE BiOS, 2018, San Francisco, California, United States 


\section{PROGRESS IN BIOMEDICAL OPTICS AND IMAGING}

\section{Optical Interactions with Tissue and Cells XXIX}

E. Duco Jansen

Hope Thomas Beier

Editors

29-30 January 2018

San Francisco, California, United States

Sponsored and Published by

SPIE 
The papers in this volume were part of the technical conference cited on the cover and title page. Papers were selected and subject to review by the editors and conference program committee. Some conference presentations may not be available for publication. Additional papers and presentation recordings may be available online in the SPIE Digital Library at SPIEDigitallibrary.org.

The papers reflect the work and thoughts of the authors and are published herein as submitted. The publisher is not responsible for the validity of the information or for any outcomes resulting from reliance thereon.

Please use the following format to cite material from these proceedings:

Author(s), "Title of Paper," in Optical Interactions with Tissue and Cells XXIX, edited by E. Duco Jansen, Hope T. Beier, Proceedings of SPIE Vol. 10492 (SPIE, Bellingham, WA, 2018) Seven-digit Article CID Number.

ISSN: 1605-7422

ISSN: 1996-756X (electronic)

ISBN: 9781510614697

ISBN: 9781510614703 (electronic)

Published by

SPIE

P.O. Box 10, Bellingham, Washington 98227-0010 USA

Telephone +1 3606763290 (Pacific Time) · Fax +1 3606471445

SPIE.org

Copyright @ 2018, Society of Photo-Optical Instrumentation Engineers.

Copying of material in this book for internal or personal use, or for the internal or personal use of specific clients, beyond the fair use provisions granted by the U.S. Copyright Law is authorized by SPIE subject to payment of copying fees. The Transactional Reporting Service base fee for this volume is $\$ 18.00$ per article (or portion thereof), which should be paid directly to the Copyright Clearance Center (CCC), 222 Rosewood Drive, Danvers, MA 01923. Payment may also be made electronically through CCC Online at copyright.com. Other copying for republication, resale, advertising or promotion, or any form of systematic or multiple reproduction of any material in this book is prohibited except with permission in writing from the publisher. The CCC fee code is 0277$786 \times / 18 / \$ 18.00$.

Printed in the United States of America.

Publication of record for individual papers is online in the SPIE Digital Library.

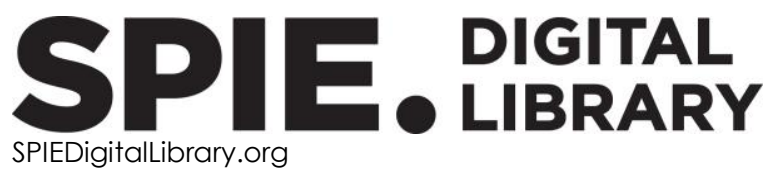

Paper Numbering: Proceedings of SPIE follow an e-First publication model. A unique citation identifier (CID) number is assigned to each article at the time of publication. Utilization of CIDs allows articles to be fully citable as soon as they are published online, and connects the same identifier to all online and print versions of the publication. SPIE uses a seven-digit CID article numbering system structured as follows:

- The first five digits correspond to the SPIE volume number.

- The last two digits indicate publication order within the volume using a Base 36 numbering system employing both numerals and letters. These two-number sets start with 00, 01, 02, 03, 04, 05, 06, 07, 08, 09, OA, OB ... 0Z, followed by 10-1Z, 20-2Z, etc. The CID Number appears on each page of the manuscript. 


\title{
Contents
}

\author{
$\checkmark$ Authors \\ vii Conference Committee
}

\section{SESSION 1 ULTRAFAST PULSED LASER INTERACTIONS}

1049204 Infrared laser damage thresholds in corneal tissue phantoms using femtosecond laser pulses [10492-3]

1049205 Femtosecond laser assisted photo-transfection and differentiation of mouse embryonic stem cells [10492-4]

1049206 Highlighting the nuances behind interaction of picosecond pulses with human skin: relating distinct laser-tissue interactions to their potential in cutaneous interventions

[10492-44]

\section{SESSION 2 PHOTOTHERMAL EFFECTS}

1049207 Porcine skin damage thresholds for pulsed nanosecond-scale laser exposure at $1064 \mathrm{~nm}$ [10492-6]

1049209 Photothermal effect of infrared lasers on ex vivo lamb brain tissues [10492-9]

\section{SESSION 3 PHOTOMECHANICAL EFFECTS}

10492 OB Performance of Er:YAG laser ablation of hard bone under different irrigation water cooling conditions [10492-11]

10492 OD Quantitative evaluation of the safety of mucosal incision and submucosal dissection for colon during endoscopic submucosal dissection using carbon dioxide laser [10492-13]

\section{SESSION 4 LASER MODULATION OF CELLS}

10492 OE Myocardial electrical conduction blockade time dominated by irradiance on photodynamic reaction: in vitro and in silico study [10492-14]

$104920 \mathrm{G}$ Control of intracellular ionic concentrations by mid-infrared laser irradiation [10492-16]

SESSION 5 NOVEL APPLICATIONS OF LASERS IN BIOSYSTEMS

104920 ol Frequency of resonance of human sweat duct in different modes of operation [10492-18] 
10492 0J Continuous optical measurement system of hemolysis during a photosensitization reaction using absorption spectrum [10492-19]

10492 OK Light scattering influence in cyanobacteria suspensions inside a photobioreactor [10492-20]

10492 OM Characterization of the Cherenkov scatter function for use in superficial dose measurement from external beam radiation treatments [10492-22]

SESSION 6 OPTICAL PROPERTIES OF TISSUES

$10492 \mathrm{OP}$ Optical coefficient measurements using bulk living tissue by an optical fiber puncture with FOV change [10492-26]

$104920 Q$ Regression models for real-time estimation of optical and structural sample properties from subdiffusive spatially resolved reflectance [10492-27]

SESSION 7 NUMERICAL APPROACHES SIMULATING LASER-TISSUE INTERACTIONS

10492 OT Monte Carlo modeling of fluorescence in semi-infinite turbid media [10492-30]

10492 OV Raman Monte Carlo simulation for light propagation for tissue with embedded objects [10492-32]

POSTER SESSION

10492 0X Comparison of light absorption levels with different skin phantoms and the Monte Carlo simulation using Fourier-domain optical coherence tomography [10492-33]

$104920 Z$ Effect of two laser photobiomodulation application protocols on the viability of random skin flap in rats [10492-35]

1049210 Assessment of varying width illumination in hyperspectral push-broom system for scattering anisotropy measurements [10492-36]

1049215 Fullerene C60 and graphene photosensibiles for photodynamic virus inactivation [10492-41]

1049216 Focusing light through random photonic layers by four-element division algorithm [10492-43]

1049217 Deep-tissue two-photon imaging in brain and peripheral nerve with a compact high-pulse energy ytterbium fiber laser [10492-45] 


\title{
Authors
}

Numbers in the index correspond to the last two digits of the seven-digit citation identifier (CID) article numbering system used in Proceedings of SPIE. The first five digits reflect the volume number. Base 36 numbering is employed for the last two digits and indicates the order of articles within the volume. Numbers start with 00, 01, 02, 03, 04, 05, 06, 07, 08, 09, OA, OB...0Z, followed by 10-12, 20-2Z, etc.

\author{
Afanasyev, M., 15 \\ Anfimov, P., 15 \\ Arai, Tsunenori, OE, OJ, OP \\ Arce-Diego, J. L., OK \\ Assis, L., $0 Z$ \\ Avó, L. R. S., OZ \\ Awazu, Kunio, OD \\ Belousova, I., 15 \\ Beltrán Bernal, Lina M., OB \\ Boretsky, Adam R., 04, 07 \\ Bossini, P. S., OZ \\ Botchkareva, Natalia V., 06 \\ Brost, Eric, OM \\ Bürmen, Miran, $0 Q$ \\ Bykovskaya, E., 15 \\ Caldwell, John H., 17 \\ Cattin, Philippe C., OB \\ Clary, Joseph E., 04 \\ DeLisi, Michael P., 07 \\ Doi, Marika, OP \\ Dougakiuchi, T., OG \\ Fang, Longjie, 16 \\ Fanjul-Vélez, F., OK \\ Finlay, Jarod C., OT \\ Fontaine, Arjun K., 17 \\ Friederich, Niklaus, OB \\ Gibson, Emily A., 17 \\ Grishkanich, A., 15 \\ Gülsoy, Murat, 09 \\ Hamada, R., OJ \\ Hazama, Hisanao, OD \\ Honda, Norihiro, OD \\ Hvorostovsky, A., 15 \\ Ivančič, Matic, $O Q$ \\ Jaafar, Humaira Bte, OV \\ Jo, Hang Chan, OX \\ Kancer, A., 15 \\ Kawase, Kodo, Ol \\ Kim, Dae Yu, OX \\ Kim, Jae Hun, OX \\ Kinumura, Kento, 0 \\ Kirchner, Matthew S., 17 \\ Kiselev, O. 15 \\ Kiselev, V., 15 \\ Kosa, Gabor, OB \\ Krisko, T., 15 \\ Kudashev, I., 15 \\ Kumru, Semih S., 07 \\ Kustikova, M., 15
}

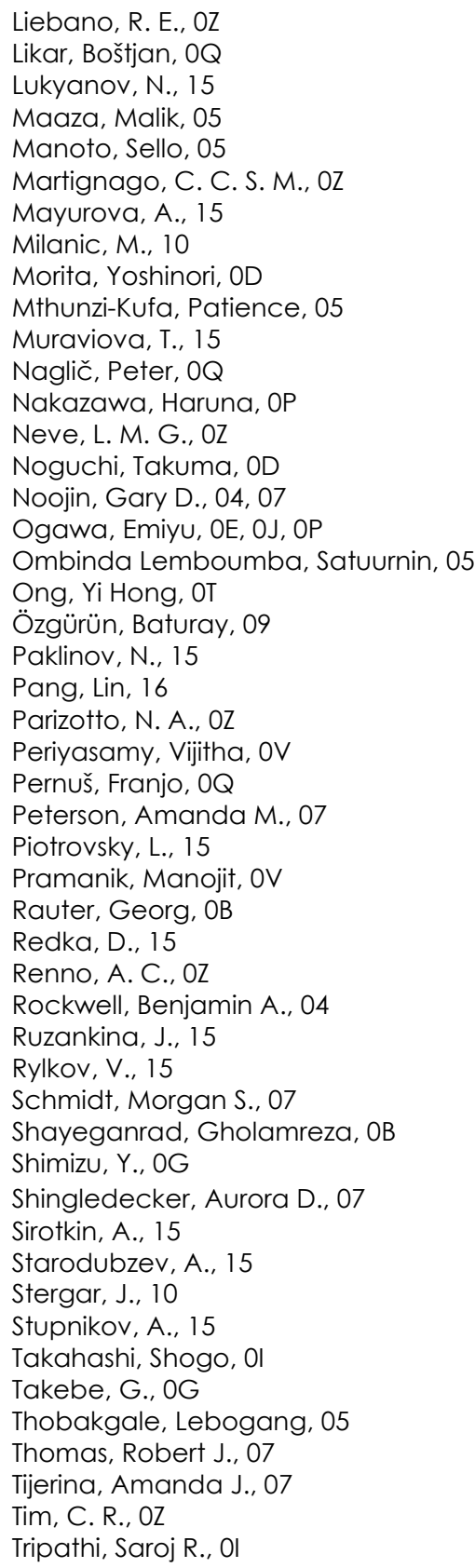


Uzunbajakava, Natallia E., 06

Varghese, Babu, 06

Verhagen, Rieko, 06

Vogel, Alfred, 06

Watanabe, Yoichi, OM

Weir, Richard F., 17

Yamauchi, T., OG

Zam, Azhar, OB

Zarubaev, V., 15

Zelechowski, Marek, OB

Zhang, Xicheng, 16

Zhu, Timothy C., OT

Zuo, Haoyi, 16

Proc. of SPIE Vol. 10492 1049201-6

Downloaded From: https://www.spiedigitallibrary.org/conference-proceedings-of-spie on 26 Apr 2023 Terms of Use: https://www.spiedigitallibrary.org/terms-of-use 


\title{
Conference Committee
}

\author{
Symposium Chairs
}

James G. Fujimoto, Massachusetts Institute of Technology

(United States)

R. Rox Anderson, Wellman Center for Photomedicine, Massachusetts General Hospital (United States) and Harvard Medical School

(United States)

Program Track Chair

Steven L. Jacques, Tufts University (United States)

Conference Chairs

E. Duco Jansen, Vanderbilt University (United States)

Hope Thomas Beier, Air Force Research Laboratory (United States)

Conference Program Committee

Randolph Glickman, The University of Texas Health Science Center at San Antonio (United States)

Bennett L. Ibey, Tri Service Research Laboratory (United States)

Steven L. Jacques, Tufts University (United States)

Beop-Min Kim, Korea University (Korea, Republic of)

Alexander J. Makowski, Prozess Technologie (United States)

Jessica C. Ramella-Roman, Florida International University

(United States)

Marissa Nicole Rylander, Virginia Polytechnic Institute and State

University (United States)

Zachary D. Taylor, University of California, Los Angeles (United States)

Robert J. Thomas, Air Force Research Laboratory (United States)

Alfred Vogel, Universität zu Lübeck (Germany)

Gerald J. Wilmink, WiseWear Corporation (United States)

\section{Session Chairs}

1 Ultrafast Pulsed Laser Interactions

Hope Thomas Beier, Air Force Research Laboratory (United States)

2 Photothermal Effects

Joel N. Bixler, Texas A\&M University (United States) 
3 Photomechanical Effects

Nathaniel Pope, Air Force Research Laboratory (United States)

$4 \quad$ Laser Modulation of Cells

Michael L Denton, Tri Service Research Laboratory (United States)

5 Novel Applications of Lasers in Biosystems

Hope Thomas Beier, Air Force Research Laboratory (United States)

6 Optical Properties of Tissues

Alexandra J. Walsh, University of Wisconsin-Madison (United States)

$7 \quad$ Numerical Approaches Simulating Laser-Tissue Interactions

Michael Delisi, Engility Corporation (United States) and Air Force Research Laboratory (United States) 